\title{
OSTEOPROTECTIVE EFFECTS OF 'ANTI-DIABETIC' POLYHERBAL MIXTURE IN TYPE 1 DIABETIC RATS
}

\author{
Aleksandra PETROVIĆ*, Višnja MADIĆ, Marina JUŠKOVIĆ, \\ Ljubiša ĐORĐEVIĆ, Perica VASILJEVIĆ \\ Department of Biology and Ecology, Faculty of Sciences and Mathematics, University of Niš, \\ Višegradska 33, 18000 Niš, Serbia
}

(Received 18 March, Accepted 26 July 2021)

\begin{abstract}
Bone loss leading to osteopenia and osteoporosis is a frequent secondary complication of diabetes. This study aimed to evaluate the value of a traditionally used 'anti-diabetic' polyherbal mixture as a possible remedy for the prevention of this complication. Diabetes was induced in Wistar female rats with a single intraperitoneal injection of alloxan monohydrate. The animals with blood glucose higher than $20 \mathrm{mmol} / \mathrm{L}$ for 14 consecutive days were considered diabetic. For the next 14 days, animals were treated with two concentrations of the polyherbal mixture (10 and $20 \mathrm{~g}$ of dry plant material/ $\mathrm{kg})$. Bone histopathology was evaluated using the H\&E and Masson's trichrome staining. Alloxan-induced diabetes triggered bone histological changes characteristic for the development of osteopenia and osteoporosis and treatment with the polyherbal decoction restored these histopathological changes of the bones to the healthy animal level. At the same time, treatment with these tested doses has shown no adverse effects. These findings suggest that this mixture might be used as a remedy for the prevention of diabetic bone loss.
\end{abstract}

Key words: diabetes, osteoprotective, polyherbal mixture, traditional medicine

\section{INTRODUCTION}

Diabetes mellitus is a chronic metabolic disease where lack of insulin and/or insulin resistance results in constant hyperglycaemia, accumulation of advanced glycation end-products (AGE), excessive production of reactive oxygen species (ROS), and chronic inflammation [1-3]. Chronic hyperglycaemia, together with elevated levels of AGE and ROS cause a decrease in bone mineralization and osteocyte differentiation as well as an increase in apoptosis of osteocytes, decrease of bone collagen and, finally, accelerated bone resorption [1,4-12]. Over time, these pathological conditions may result in the development of osteopenia and osteoporosis [13-16]. As a consequence, there is an increased risk of bone fractures in the diabetic compared to the non-

\footnotetext{
*Corresponding author: e-mail: aleksandra.petrovic2@pmf.edu.rs
} 
diabetic population, which is an additional burden to their already reduced quality of life [17-19].

Bone density is reduced by 22 to $37 \%$ in type 1 diabetic patients [20]. Although there were some cases where a reduction in bone density and diabetes is diagnosed at the same time, usually, the severity of osteoporosis is directly proportional to the elapsed time since the onset of diabetes [21-23]. Subsequently, the prevalence of osteoporosis rapidly increases with age in both type 1 and type 2 diabetic patients and this incidence is higher in menopausal women than in men [24].

For centuries, medicinal plants have been used as ethnopharmacological remedies in the treatment of osteopenia and osteoporosis [25]. However, many studies have shown that, when addressing complex diseases, treatments based on polyherbal mixtures lead to a better therapeutic outcome than treatments with a single medicinal plant $[26,27]$. Similarly, one of the most commonly used polyherbal mixtures in the Balkan countries, which is made of blackberry (Rubus fruticosus L., Rosaceae) and blueberry (Vaccinium myrtillus L., Ericaceae) leaves, tormentil (Potentilla erecta (L.) Räuschel, Rosaceae) roots, St. Benedict's herb (Geum urbanum L., Rosaceae) aerial parts and kidney bean (Phaseolus vulgaris L., Fabaceae) pods [28], has much lower toxicity and higher anti-toxicity than its ingredients when used alone [29]. Moreover, our previous study showed that this polyherbal mixture has high hypoglycemic and anti-inflammatory activities due to its high antioxidant properties due to the synergistic effect of its active compounds, i.e., isoquercetin, rutin, quercitrin, arbutin, hyperoside, astragalin, trifolin, as well as gallic, quinic and caftaric acid. [30]. However, when used in high concentrations, this traditionally used 'anti-diabetic' polyherbal preparation [28,29] shows low levels of nephrotoxicity and hepatotoxicity [30].

Having in mind that maintenance of normal glycaemic values and regulation of oxidative stress may prevent the development of osteopenia and osteoporosis [31,32] this study aimed to further assess both the other potential adverse effects if used in high concentrations, as well as the potential osteoprotective activity of the traditionally used polyherbal mixture through evaluation of its effects on the histopathological changes of healthy and diabetic female rats bones.

\section{MATERIALS AND METHODS}

\section{Collection and extraction of plant material}

V. myrtillus, P. erecta, R. fruticosus, G. urbanum and P. vulgaris were collected in Serbia during 2017 (Stara Planina Mt., Vlasina, Sićevo Gorge, Gornja Koritnica and Niška Banja, respectively) and taxonomically identified. Voucher specimens were deposited at the herbarium collection of the Faculty of Science and Mathematics, University of Niš, under the accession numbers HMN 13717-13721.

The plant material was dried in dark conditions at room temperature for 2-3 weeks and finely ground afterwards. The 'anti-diabetic' polyherbal mixture was prepared 
according to the traditionally used recipe, i.e., $V$. myrtillus leaves, $P$. erecta roots, $R$. fruticosus leaves, G. urbanum aerial parts and P. vulgaris pods were thoroughly mixed [28]. The extract was prepared according to traditional use, i.e., in the form of a decoction. $100 \mathrm{~g}$ of the herbal mixture was boiled in $1000 \mathrm{~mL}$ of distilled water until half of the liquid evaporated. The obtained extract was filtered, and the rest of the solvent was removed using a vacuum evaporator (IKA RV10 Rotary Evaporator with HB10 Bath, Gaithersburg).

\section{Animals}

Sixty female Wistar rats 10 weeks old (200-250 g) were obtained from the Institute of Biomedical Research, Medical Faculty, Niš, Serbia. The animals were treated according to the principles of the Care and Use of Laboratory Animals and approved by the Ethical Committee of the Faculty of Medicine, the University of Niš (No. 323-0701762/2019-05/5). Animals were maintained under standard husbandry conditions with a temperature of $23 \pm 2^{\circ} \mathrm{C}$, relative humidity $55 \pm 10 \%$ and $12 / 12 \mathrm{~h} \mathrm{light} / \mathrm{dark}$ cycle. Animals were fed with standard rat food pellets and water provided ad libitum.

\section{Evaluation of polyherbal mixture effect on healthy animals' bone structure}

The potential effect of polyherbal mixture histopathological changes of the healthy animals' bones was evaluated by following the principles of OECD 407 (Repeated Dose 28-day Oral Toxicity (OECD 2018)), as previously described [30]. Briefly, twenty healthy animals were randomized into four treatment groups of five rats each as follows:

- Group HC: normoglycemic rats that received $1 \mathrm{ml}$ of water only,

- Group H-10: normoglycemic rats that received $1 \mathrm{ml}$ of polyherbal mixture decoction (10 g of dry plant material $/ \mathrm{kg}$ ),

- Group H-20: normoglycemic rats that received $1 \mathrm{ml}$ of polyherbal mixture decoction (20 g of dry plant material $/ \mathrm{kg}$ ),

- Group H-40: normoglycemic rats that received $1 \mathrm{ml}$ of polyherbal mixture decoction (40 $\mathrm{g}$ of dry plant material $/ \mathrm{kg}$ ).

Animals were treated every morning for 28 consecutive days, per os. The bodyweight was recorded daily.

\section{Evaluation of polyherbal mixture effect on diabetic animals' bone structure}

As previously described, diabetes was induced by a single intraperitoneal injection of the freshly prepared alloxan monohydrate dissolved in ice-cold saline $(150 \mathrm{mg} / \mathrm{kg}$ ), while healthy control received PBS only [30]. To prevent hypoglycaemia, $1 \mathrm{~h}$ after the alloxan injection, the rats have been treated with a 5\% glucose solution over the 
next $48 \mathrm{~h}$, ad libitum [33]. Fourteen days after the alloxan monohydrate injection, the animals with blood glucose $>20 \mathrm{mmol} / \mathrm{L}(\mathrm{n}=25)$ were considered diabetic. Animals were randomized into six treatment groups of five rats each as follows:

- Group DC: diabetic rats that that received $1 \mathrm{ml}$ of water only,

- Group D-10: diabetic rats that received $1 \mathrm{ml}$ of polyherbal mixture decoction (10 g of dry plant material $/ \mathrm{kg}$ ),

- Group D-20: diabetic rats that received $1 \mathrm{ml}$ of polyherbal mixture decoction (20 g of dry plant material $/ \mathrm{kg}$ ),

- Group I: diabetic rats that received insulin glargine $(13 \mathrm{IU} / \mathrm{kg})$,

- Group M: diabetic rats that received $1 \mathrm{ml}$ of metformin dissolved in water (150 mg/kg),

- Group HC: normoglycemic rats that received $1 \mathrm{ml}$ of water only.

Water, metformin and the herbal mixture were administered by oral gavage, and insulin by intraperitoneal injection, every morning for 14 consecutive days. The bodyweight was recorded daily.

\section{Histopathological studies}

Twenty-four hours after the last treatment, animals were sacrificed using intraperitoneal injection of a high dose $(300 \mathrm{mg} / \mathrm{kg})$ of ketamine $(10 \%$ Ketamidor, Richter pharma, Austria) followed by cardiopuncture and removal of blood. The whole left femurs were collected, washed with ice-cold saline, fixed in 10\% formalin, and decalcified in EDTA $(10 \%, \mathrm{pH} 7.4)$. The distal metaphyses were embedded in paraplast, cut into 5 $\mu \mathrm{m}$ thick tissue sections (Leica RM2125 RT, Germany), and subjected to hematoxylin and eosin (H\&E) and Masson's trichrome staining [34]. Ten sections per sample of cortical bone were imaged using a Leica microscope (Leica DM2500, Germany) at $400 \times$ magnification, while the whole bone sections were imaged using Leica Stereo Microscope (Leica M205 C, Germany) at 20x magnification, and analyzed by ImageJ software (NIH, USA).

Having in mind that one of the key factors in the development of diabetic osteoporosis is the bone loss evolved as a consequence of impaired osteocyte function [35-37], possible osteoprotective effects of the herbal mixture were evaluated using comparative analysis of four histological parameters: the size of the bone area (B.Ar.), osteocyte lacunar density (Os.Lac.D.), size of the osteocyte lacunar area and bone collagen deposition [35,38].

The size of the bone area was calculated using a formula:

$$
\text { B.Ar. = Tt.B.Ar. }- \text { B.Ma.Ar. }
$$

where Tt.B.Ar. was the size of the total bone area and B.Ma.Ar. was the size of the bone marrow area and expressed in $\mathrm{mm}^{2}$. 
Osteocyte lacunar density was expressed as total lacunar number (Tt.L.N.) per $\mathrm{mm}^{2}$ of B. Ar. Size of the osteocyte lacunar area was expressed in $\mu \mathrm{m}^{2}$ and bone collagen depositions in $\%$.

\section{Statistical analysis}

Statistical analysis was done using GraphPad Prism 5 (GraphPad Software, La Jolla California USA). All experiments were done in pentaplicate and data were expressed as the mean \pm standard deviation. The differences between the controls and the individual dosage groups of the tested extract were analyzed by the one-way analysis of variance (ANOVA) followed by the Tukey's Multiple Comparison Test. Statistical differences were accepted if $\mathrm{p}$ was less than 0.05 .

\section{RESULTS}

\section{The effect of the polyherbal mixture on healthy animals bone histology}

Treatment with the tested polyherbal mixture decoction produced no changes in the size of the healthy animals bone area (Figure 1C) or osteocyte lacunar area (Figure $1 \mathrm{E})$.

Additionally, treatment with tested decoction did not have any effect on experimental animals bone collagen deposition, as shown in Figure 2C.

However, animals treated with the highest tested concentration $(40 \mathrm{~g} / \mathrm{kg})$ had increased osteocyte lacunar density $\left(748.79 \pm 41.57 / \mathrm{mm}^{2}\right)$ compared to the untreated healthy controls $\left(673.01 \pm 16.94 / \mathrm{mm}^{2}\right)$, as shown in Figure 1D.

\section{The effect of the polyherbal mixture on diabetic animals bone histology}

As shown in Figure 3C, size of the bone area was significantly decreased $(p<0.01)$ in untreated diabetic animals $\left(3.25 \pm 0.51 \mathrm{~mm}^{2}\right)$ compared to the healthy control ones $\left(4.71 \pm 0.61 \mathrm{~mm}^{2}\right)$. Administration of polyherbal mixture only slightly increased the bone area $\left(3.92 \pm 0.21\right.$ and $3.92 \pm 0.51 \mathrm{~mm}^{2}$, respectively) compared to the diabetic controls, while treatments with insulin and metformin restored this parameter to the healthy animal level $\left(4.73 \pm 0.48\right.$ and $4.23 \pm 0.56 \mathrm{~mm}^{2}$, respectively).

Moreover, osteocyte lacunar density was extremely decreased $(\mathrm{p}<0.001)$ in the DC group of animals $\left(402.36 \pm 28.34 / \mathrm{mm}^{2}\right)$ compared to the HC group $(673.01 \pm 16.94$ $/ \mathrm{mm}^{2}$ ). Both treatments with insulin and with a higher concentration of polyherbal decoction $(20 \mathrm{~g} / \mathrm{kg})$ significantly increased osteocyte lacunar density $(572.92 \pm 21.21$ and $554.11 \pm 27.34 / \mathrm{mm}^{2}$, respectively) compared to the DC group and brought it to the healthy animal level (Figure 3D). 
A
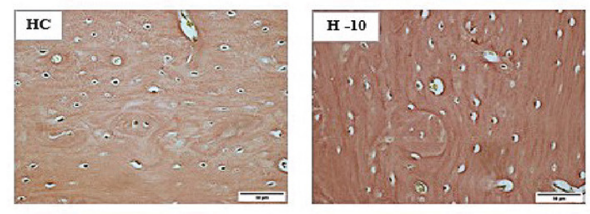

B
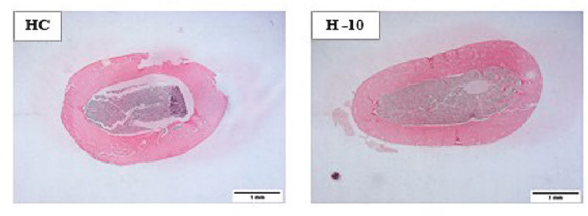

C

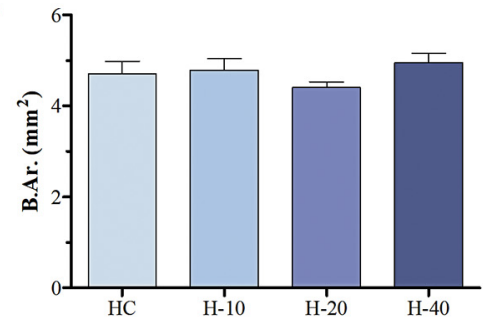

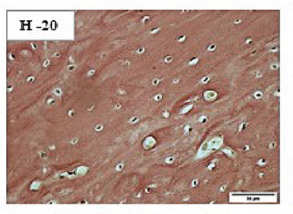
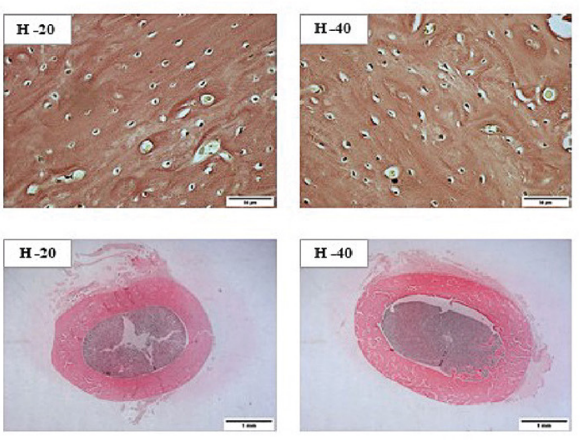

D

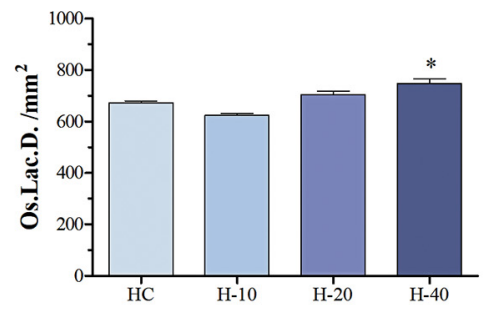

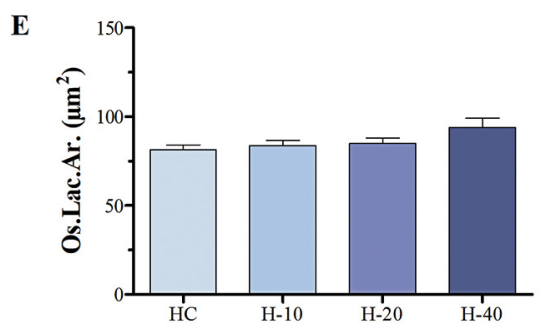

Figure 1. 'Anti-diabetic' polyherbal mixture effects on healthy experimental animals cortical bone: (A) H\&E stained sections of femoral cortical bone. Scale bar $50 \mu \mathrm{m}$. Magnification 400x; (B) H\&E stained femoral cortical bone cross-section. Scale bar $1 \mathrm{~mm}$. Magnification 20x; (C) Effect of polyherbal mixture treatment on the femoral cortical bone area; (D) Effect of polyherbal mixture treatment on osteocyte lacunar density; (E) Effects of polyherbal mixture treatment on osteocyte lacunar area; HC: Healthy control; H-10: Polyherbal mixture $10 \mathrm{~g} / \mathrm{kg}$; H-20: Polyherbal mixture $20 \mathrm{~g} / \mathrm{kg}$; H-40: Polyherbal mixture $40 \mathrm{~g} / \mathrm{kg}$; B.Ar.: Bone Area; Os.Lac.D.: Osteocyte Lacunar Density; Os.Lac.Ar.: Osteocyte Lacunar Area. Data were expressed as the mean \pm standard deviation, $n=5$. ${ }^{*} \mathrm{p}<0.05$ compared to the HC group. 
A

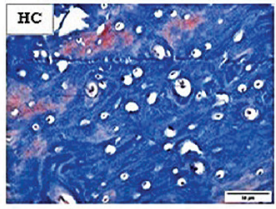

B

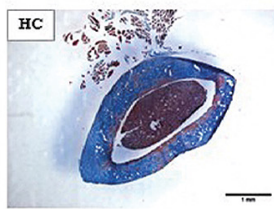

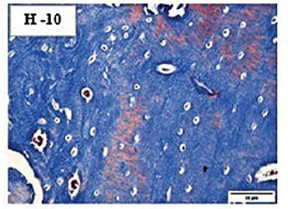

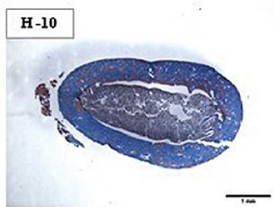

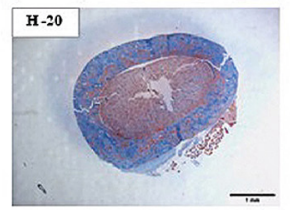
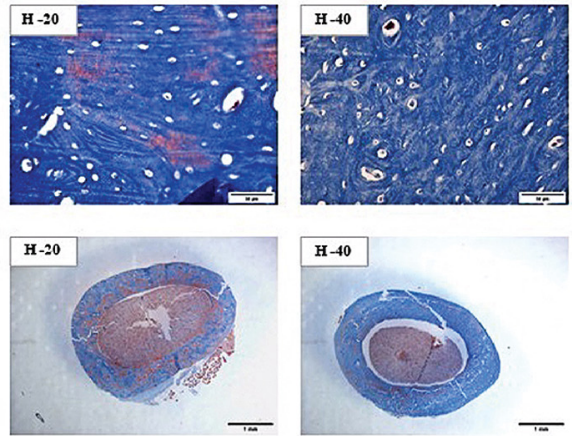

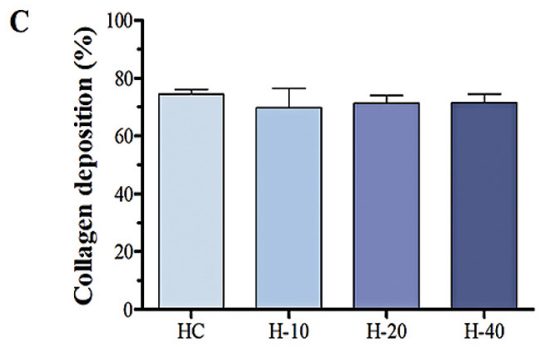

Figure 2. 'Anti-diabetic' polyherbal mixture effects on healthy experimental animals bone collagen: (A) Masson's trichrome stained sections. Scale bar $50 \mu \mathrm{m}$ magnification 400x; (B) Masson's trichrome stained femoral cortical bone cross-section. Scale bar $1 \mathrm{~mm}$. Magnification 20x; (C) HC: Healthy control; H-10: Polyherbal mixture $10 \mathrm{~g} / \mathrm{kg}$; H-20: Polyherbal mixture $20 \mathrm{~g} / \mathrm{kg} ; \mathrm{H}-40$ : Polyherbal mixture $40 \mathrm{~g} / \mathrm{kg}$. Data were expressed as the mean \pm standard deviation, $\mathrm{n}=5$.

Additionally, the size of the osteocyte lacunar area was significantly decreased $(\mathrm{p}<0.001)$ in the untreated diabetic group $\left(66.05 \pm 2.62 \mu \mathrm{m}^{2}\right)$ compared to the healthy one $(81.52$ $\pm 5.89 \mu \mathrm{m}^{2}$ ). Administration of the herbal mixture in both tested concentrations completely normalized the osteocyte lacunar area $(81.02 \pm 6.41$ and $83.75 \pm 7.17$, in D-10 and D-20 experimental groups, respectively), while treatments with insulin and metformin did not have any effect on this parameter (Figure 3E).

At the same time, the deposition of collagen in the bone tissue was significantly decreased in untreated diabetic animals (52.2 $4 \pm 1.58 \%)$ compared to the healthy ones $(74.57 \pm 3.52 \%)$. Fourteen days of administration of the lower tested dose $(10 \mathrm{~g} /$ $\mathrm{kg}$ ) of polyherbal mixture significantly increased deposition of bone collagen (70.84 \pm $4.88 \%$ ) compared to the diabetic control, while treatment with a higher dose $(20 \mathrm{~g} / \mathrm{kg})$ completely restored this parameter $(75.59 \pm 6.91 \%)$ to the healthy animal level. In the same manner, treatments with both metformin and insulin increased the deposition of collagen in diabetic animals bones $(73.77 \pm 9.78$ and $85.61 \pm 4.27 \%$, respectively), compared to the DC group (Figure 4C). 
A
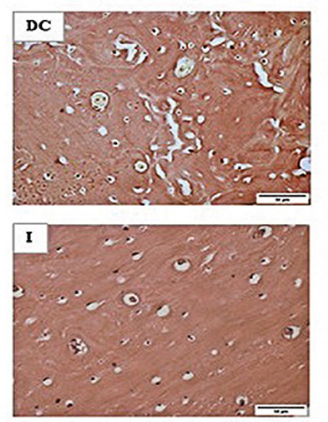

B
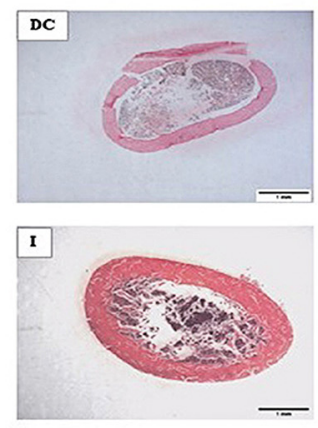

C

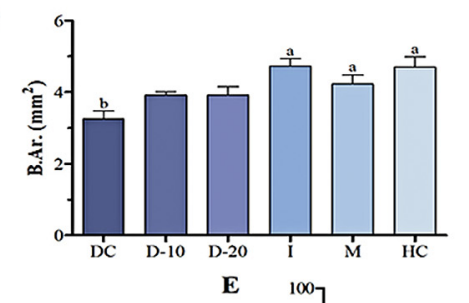

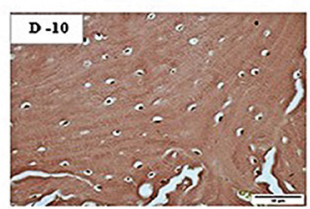
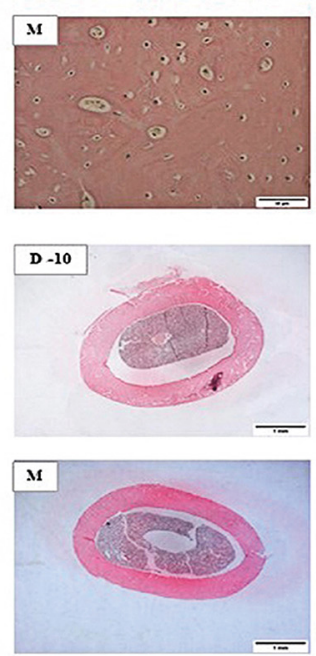

D
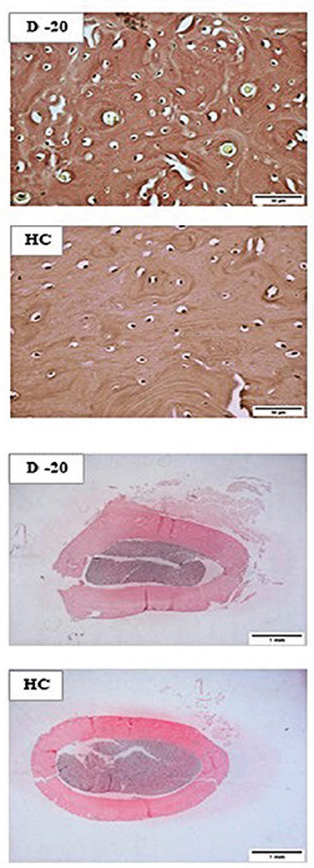
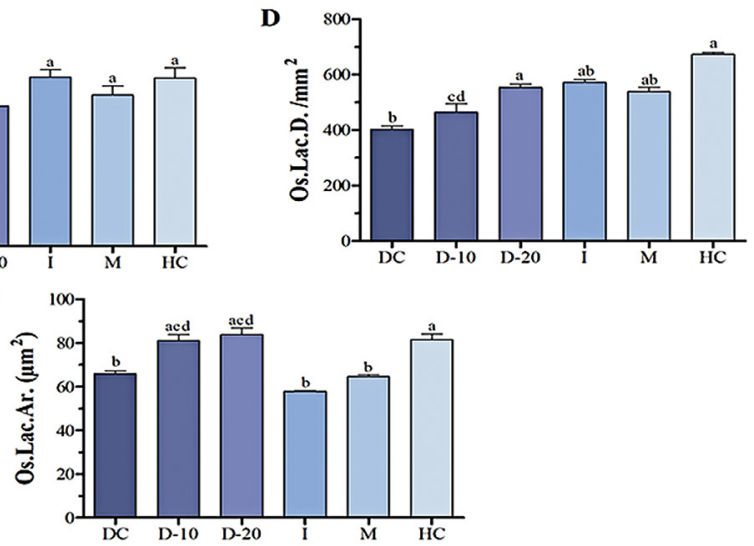

Figure 3. 'Anti-diabetic' polyherbal mixture effects on diabetic experimental animals cortical bone: (A) H\&E stained sections of femoral cortical bone. Scale bar $50 \mu \mathrm{m}$. Magnification 400x; (B) H\&E stained femoral cortical bone cross-section. Scale bar $1 \mathrm{~mm}$. Magnification 20x; (C) Effect of polyherbal mixture treatment on the femoral cortical bone area; (D) Effect of polyherbal mixture treatment on osteocyte lacunar density; (E) Effects of polyherbal mixture treatment on osteocyte lacunar area; DC: Diabetic control; I: Insulin; M: Metformin; D-10: Polyherbal mixture $10 \mathrm{~g} / \mathrm{kg}$; D-20: Polyherbal mixture $20 \mathrm{~g} / \mathrm{kg}$; HC: Healthy control; B.Ar.: Bone Area; Os.Lac.D.: Osteocyte Lacunar Density; Os.Lac.Ar.: Osteocyte Lacunar Area. Data were expressed as the mean \pm standard deviation, $\mathrm{n}=5 .{ }^{\mathrm{a}} \mathrm{p}<0.05$ compared to the DC group; ${ }^{b} \mathrm{p}<0.05$ compared to the HC group; ${ }^{\mathrm{c}} \mathrm{p}<0.05$ compared to the I group; ${ }^{\mathrm{d}} \mathrm{p}<0.05$ compared to the M group. 
A
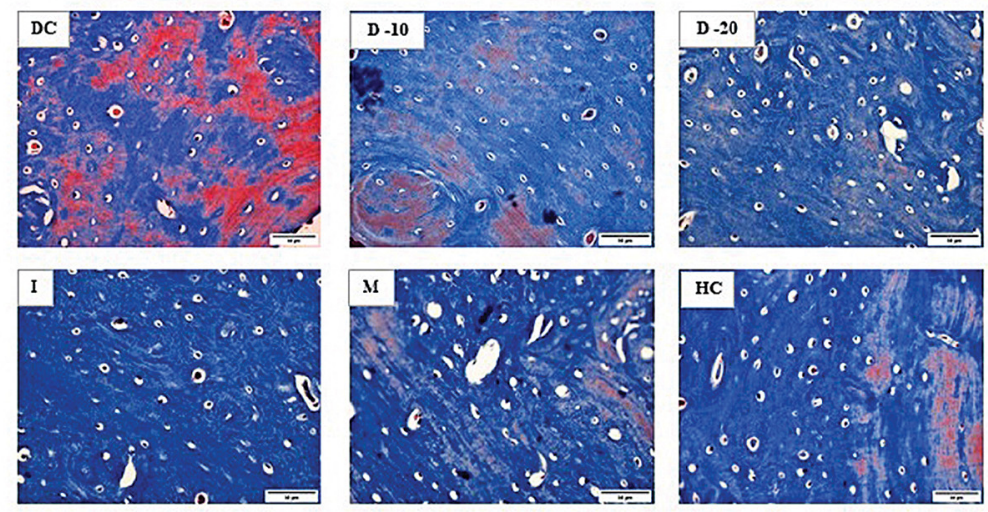

B
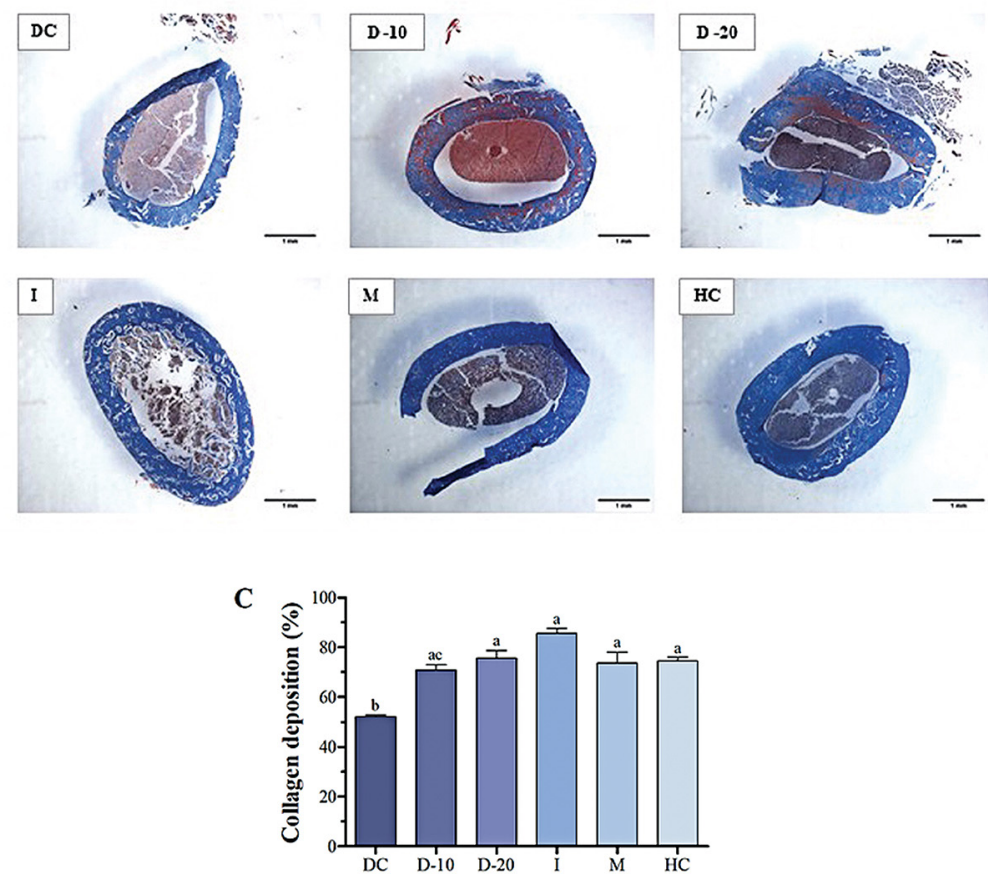

Figure 4. 'Anti-diabetic' polyherbal mixture effects on diabetic experimental animals bone collagen: (A) Masson's trichrome stained sections. Scale bar $50 \mu \mathrm{m}$ magnification 400x; (B) Masson's trichrome stained femoral cortical bone cross-section. Scale bar $1 \mathrm{~mm}$. Magnification 20x; (C) DC: Diabetic control; I: Insulin; M: Metformin; D-10: Polyherbal mixture $10 \mathrm{~g} / \mathrm{kg}$; D-20: Polyherbal mixture $20 \mathrm{~g} / \mathrm{kg}$; HC: Healthy control. Data were expressed as the mean \pm standard deviation, $\mathrm{n}=5$. ${ }^{\mathrm{a}} \mathrm{p}<0.05$ compared to the $\mathrm{DC}$ group; ${ }^{\mathrm{b}} \mathrm{p}<0.05$ compared to the HC group; ${ }^{\mathrm{p}} \mathrm{p}<0.05$ compared to the I group; ${ }^{\mathrm{d}} \mathrm{p}<0.05$ compared to the $\mathrm{M}$ group. 


\section{DISCUSSION}

This study aimed to evaluate the value of a traditionally used 'anti-diabetic' polyherbal mixture as a possible remedy for diabetic bone loss prevention.

Histopathological analysis of healthy animals bones treated with low and middle concentration (10 and $20 \mathrm{~g} / \mathrm{kg}$ ) of the polyherbal mixture showed no changes in any of the analyzed histological parameters (Figure 1C, 1E, Figure 2C). However, four weeks of treatment with the highest tested concentration $(40 \mathrm{~g} / \mathrm{kg})$ increased osteocyte lacunar density which may lead to the increase in bone density and the development of osteopetrosis (Figure 1D) [39-41]. These findings are an additional proof that this polyherbal mixture, as the majority of medicinal plants, when applied in high doses may cause adverse effects [42], not only in terms of hepatotoxicity and nephrotoxicity [30] but also as a potential trigger of osteopetrosis. Because of that, for the evaluation of potential osteoprotective affect the doses of 10 and $20 \mathrm{~g} / \mathrm{kg}$ of the polyherbal mixture have been chosen.

The osteoprotective effect of the traditionally used herbal mixture was evaluated using the alloxan-induced diabetic rat model. This model is appropriate because alloxaninduced oxidative stress inhibits differentiation of osteoblasts into osteocytes which results in the decreased number of osteocytes per bone area $[4,36,37,43,44]$, that closely resembles the situation seen in human diabetic osteopenia $[35,37]$.

Histopathological analysis of diabetic animals bones showed that treatment with alloxan significantly decreased osteocyte lacunar density compared to the healthy animals $(\mathrm{p}<0.001)$, indicating that the model was successful. Interestingly, two weeks of treatment with the 'anti-diabetic' polyherbal mixture was even more effective than treatment with metformin in normalizing the density of osteocyte lacunae (Figure 3D). These results are in concordance with the study of Domazetovic and associates [41] where treatment with $V$. myrtillus extract protected both osteocytes and their precursors from oxidative stress. Additionally, gallic acid, one of the most abundant bioactive compounds in this polyherbal mixture [30] is well known for its anti-osteoporotic activities [40].

Moreover, the size of the osteocyte lacunar area was extremely decreased in the untreated diabetic group of animals compared to the healthy ones $(p<0.001)$, while 14 days of treatment with both tested concentrations of the herbal mixture completely restored this pathological change and brought it to the healthy animal level. Having in mind that chronic hyperglycaemic environment may cause changes in both shape and size of osteocyte lacunar area [40], observed osteoprotective mechanism of the tested polyherbal mixture can be explained by its outstanding hypoglycemic activity observed in our previous study [30].

Interestingly, treatment with the highest tested concentration of herbal mixture restored both the size of the bone area as well as the density of osteocyte lacunae to the healthy animal level, similarly to the diabetic control groups treated with 
insulin in metformin (Figure 3C, 3D). Having in mind the fact that both insulin and metformin have proven osteoprotective effects, where lack of available insulin leads to the inactivation of osteoblasts and subsequent osteopenia [45-48], while metformin stimulates proliferation of osteoblasts [49], inhibits activation of osteoblasts, and increases bone mineral density through stimulation of osteoprotegerin and inhibition of RANKL expression [50,51], we might notice the potential of the tested herbal mixture as a herbal remedy for diabetic osteoporosis.

Additionally, we have observed a decreased level of bone collagen in untreated diabetic animals (Figure 4C), which is one of the well-known characteristics of alloxan-induced diabetic rats $[19,52,53]$. By the end of the experiment, treatment with polyherbal mixture completely normalized the deposition of bone collagen in all experimental animals. We noticed that the herbal mixture $(20 \mathrm{~g} / \mathrm{kg})$ was more successful in stimulating the synthesis of collagen compared to metformin, which is known as a drug capable of stimulating the synthesis of collagen type I and bone matrix [54].

Having in mind that decoction of this herbal mixture is characterized not only with a high content of polyphenols and flavonoids but also with the presence of even 10 biologically active compounds, i.e. isoquercetin, rutin, quercitrin, arbutin, hyperoside, astragalin, trifolin as well as gallic, quinic and caftaric acid [30], the results of this study are in agreement with previous studies where many naturally derived polyphenols, due to the high antioxidative activity [55-58] are well known for osteoprotective activities [59-61]. Namely, isoquercetin, the most abundant bioactive compound in the tested decoction [30], decreases the elevated level of oxidative stress in diabetic rats [62] and has anti-osteoporotic effect in ovariectomised rats [63]. Moreover, rutin increases bone density by inhibition of osteoclast activity via inhibition of receptor activator of nuclear factor kappa-B ligand (RANKL), by decreasing the elevated level of ROS and through inhibition of $\mathrm{NF}-x \mathrm{~B}$ activation $[2,64,65]$. Supplementation with quercetin and arbutin ameliorates bone loss by reducing bone resorption [25,31,32,66-68] through the suppression of osteoclasts activity and the stimulation of osteoblast activity [6973]. Hyperoside protects osteoblasts from oxidative stress [74,75], while astragalin stimulates differentiation of osteoblasts [76]. Additionally, quinic acid promotes osteoblasts differentiation through activation of the $\mathrm{Wnt} / \beta$-catenin pathway, while caftaric acid modulates RunX2 and RANKL/OPG signalling pathways [77].

To the best of our knowledge, this is the first report on the in vivo evaluation of this 'anti-diabetic' polyherbal preparation osteoprotective effect.

\section{CONCLUSION}

Treatment with the 'anti-diabetic' polyherbal mixture decoction was effective in the amelioration of histopathological changes of the bones in an alloxan-induced diabetic rat model. This finding suggests that this mixture might be a candidate for possible future usage as a remedy for the prevention of diabetic osteopenia/osteoporosis. However, more studies are needed. 


\section{Acknowledgements}

The authors would like to acknowledge financial support from the Ministry of Education, Science and Technological Development of the Republic of Serbia (Agreement No 451-03-68/2020-14-200124).

\section{Authors' contributions}

AP carried out literature research, designed a study, did the microscopy and histopathology, analyzed the results and drafted the manuscript. VM conceived the study, carried out the in vivo experiments and drafted the manuscript. MJ participated in plant collecting and taxonomy. LjĐ confirmed the histopathological analysis. PV supervised of all the work. All authors read and approved the final manuscript.

\section{Declaration of conflicting interests}

The author(s) declared no potential conflicts of interest with respect to the research, authorship, and/or publication of this article.

\section{REFERENCES}

1. Bucala R, Vlassara H: Advanced glycosylation end products in diabetic renal and vascular disease. Am J Kidney Dis 1995, 26(6):875-888.

2. Wang J, Wang H: Oxidative stress in pancreatic beta cell regeneration. Oxid Med Cell Longev 2017, 2017:1930261.

3. International Diabetes Federation: IDF Diabetes Atlas, 9th edn. Brussels, Belgium: International Diabetes Federation 2019. http://www.diabetesatlas.org

4. Bai XC, Lu D, Bai J, Zheng H, Ke ZY, Li XM, Luo SQ: Oxidative stress inhibits osteoblastic differentiation of bone cells by ERK and NF- $x$ B. Biochem Biophys Res Commun 2004, 314:197-207.

5. King GL, Loeken MR: Hyperglycemia-induced oxidative stress in diabetic complications. Histochem Cell Biol 2004. 22:333-338.

6. Alikhani M, Alikhani Z, Boyd C, MacLellan CM, Raptis M, Liu R, Pischon N, Trackman PC, Gerstenfeld L, Graves DT: Advanced glycation end products stimulate osteoblast apoptosis via the MAP kinase and cytosolic apoptotic pathways. Bone 2007, 40:345-353.

7. Hamada Y, Kitazawa S, Kitazawa R, Fujii H, Kasuga M, Fukagawa M: Histomorphometric analysis of diabetic osteopenia in streptozotocin-induced diabetic mice: A possible role of oxidative stress. Bone 2007, 40:1408-1414.

8. Sanguineti R, Storace D, Monacelli F, Federici A, Odetti P: Pentosidine effects on human osteoblasts in vitro, in: Annals of the New York Academy of Sciences Blackwell Publishing Inc 2008, 1126(1):166-172.

9. Abbassy MA, Watari I, Soma K: The effect of diabetes mellitus on rat mandibular bone formation and microarchitecture. Eur J Oral Sci 2010, 118:364-369. 
10. Zhen D, Chen Y, Tang X: Metformin reverses the deleterious effects of high glucose on osteoblast function. J Diabetes Complications 2010, 24:334-344.

11. Okazaki K, Yamaguchi T, Tanaka KI, Notsu M, Ogawa N, Yano S, Sugimoto T: Advanced glycation end products (AGEs), but not high glucose, inhibit the osteoblastic differentiation of mouse stromal ST2 cells through the suppression of osterix expression, and inhibit cell growth and increasing cell apoptosis. Calcif Tissue Int 2012, 91:286-296.

12. Zheng W, Wang S, Wang J, Jin F: Periodontitis promotes the proliferation and suppresses the differentiation potential of human periodontal ligament stem cells. Int J Mol Med 2015, 36:915-922.

13. Lebovitz HE:Diagnosis, classification, and pathogenesis of diabetes mellitus. J Clin Psychiatry 2001, 62:5-9.

14. Inzerillo AM, Epstein S:. Osteoporosis and diabetes mellitus. Rev Endocr Metab Disord 2004, 5:261-268.

15. Duarte, V.M.G., Ramos, A.M.O., Rezende, L.A., Macedo, U.B.O., Brandão-Neto, J., Almeida, M.G., Rezende, A.A., 2005. Osteopenia: A bone disorder associated with diabetes mellitus. J Bone Miner Metab 23, 58-68.

16. Silva MJ, Brodt MD, Lynch MA, McKenzie JA, Tanouye KM, Nyman JS, Wang X: Type 1 diabetes in young rats leads to progressive trabecular bone loss, cessation of cortical bone growth, and diminished whole bone strength and fatigue life. J Bone Miner Res 2009, 24:1618-1627.

17. Herskind AM, Christensen K, Nørgaard-Andersen K, Andersen JF: Diabetes mellitus and healing of closed fractures. Diab Metab 1992, 18:63-64.

18. Forsén L, Meyer HE, Midthjell K, Edna TH: Diabetes mellitus and the incidence of hip fracture: Results from the Nord-Trondelag health survey. Diabetologia 1999, 42:920-925.

19. Vestergaard P, Rejnmark L, Mosekilde L: Diabetes and its complications and their relationship with risk of fractures in type 1 and 2 diabetes. Calcif Tissue Int 2009, 84:45-55.

20. Vestergaard P: Discrepancies in bone mineral density and fracture risk in patients with type 1 and type 2 diabetes - A meta-analysis. Osteoporos Int 2007, 18:427-444.

21. Hampson G, Evans C, Petitt RJ, Evans WD, Woodhead SJ, Peters JR, Ralston SH: Bone mineral density, collagen type $1 \propto 1$ genotypes and bone turnover in premenopausal women with diabetes mellitus. Diabetologia 1998, 41:1314-1320.

22. López-Ibarra P-J, Pastor MMC, Escobar-Jiménez F, Pardo MDS, González AG, Luna JDD, González AG, Requena MER, Diosdado MA:. Bone mineral density at time of clinical diagnosis of adult-onset type 1 diabetes mellitus. Endocr Pract 2001,. 7:346-351.

23. Mastrandrea LD, Wactawski-Wende J, Donahue RP, Hovey KM, Clark A, Quattrin T: Young women with type 1 diabetes have lower bone mineral density that persists over time. Diabetes Care 2008, 31:1729-1735.

24. Kristin K, Nicodemus BA, Aaron R, Folsom MD: Type 1 and Type 2 Diabetes and Incident Hip Fractures in Postmenopausal Women. Epidemiology 2001, 24:1192-1197.

25. Lim DW, Kim YT: Anti-osteoporotic effects of Angelica sinensis (Oliv.) Diels extract on ovariectomized rats and its oral toxicity in rats. Nutrients 2014, 6(10): 4362-4372.

26. Parasuraman S, Thing GS, Dhanaraj SA: Polyherbal formulation: Concept of ayurveda. Pharmacogn Rev 2014, 8(16):73-80.

27. Han X, Yang Y, Metwaly AM, Xue Y, Shi Y, Dou D: The Chinese herbal formulae (Yitangkang) exerts an antidiabetic effect through the regulation of substance metabolism and energy metabolism in type 2 diabetic rats. J Ethnopharmacol 2019, 239:111942. 
28. Künzle J: Herbs and weeds: A practical booklet on medicinal herbs Switzerland 1911.

29. Madić V, Stojanović-Radić Z, Jušković M, Jugović D, Žabar-Popović A, Vasiljević P.. Genotoxic and antigenotoxic potential of herbal mixture and five medicinal plants used in ethnopharmacology. South African J Bot 2019, 125:290-297.

30. Madić V, Petrović A, Jušković M, Jugović D, Djordjević Lj, Stojanović G, Vasiljević P: Polyherbal mixture ameliorates hyperglycemia, hyperlipidemia and histopathological changes of pancreas, kidney and liver in a rat model of type 1 diabetes. J Ethnopharmacol 2021, 265:113210.

31. Liang W, Luo Z, Ge S, Li M, Du J, Yang M, Yan M, Ye Z, Luo Z: Oral administration of quercetin inhibits bone loss in rat model of diabetic osteopenia. Eur J Pharmacol 2011, 670:317-324.

32. Abu Ayana MA, Elmasry NA, Shehata FI, Khalil NM: Efficiacy of quercetin on alveolar bone structure of rats with induced diabetes. Alexandria Dent J 2017, 42:141-146.

33. Banda M, Nyirenda J, Muzandu K, Sijumbila G, Mudenda S: Antihyperglycemic and Antihyperlipidemic Effects of Aqueous Extracts of Lannea edulis in Alloxan-Induced Diabetic Rats. Front Pharmacol 2018, 9-1099.

34. Ay B, Parolia K, Liddell RS, Qiu Y, Grasselli G, Cooper DML, Davis JE: Hyperglycemia compromises Rat Cortical Bone by Increasing Osteocyte Lacunar Density and Decreasing Vascular Canal Volume. Commun Biol 2020, 3:20.

35. Mullender MG, Van Der Meer DD, Huiskes R, Lips P: Osteocyte density changes in aging and osteoporosis. Bone 1996, 18:109-113.

36. Leite Duarte ME, da Silva RD: Histomorphometric analysis of the bone tissue in patients with non-insulin-dependent diabetes (DMNID). Rev Hosp Clin Fac Med 1996, 51:7-11.

37. Vashishth D, Gibson G, Kimura J, Schaffler MB, Fyhrie DP: Determination of bone volume by osteocyte population. Anat. Rec 2002, 267:292-295.

38. He Y, Mu C, Shen X, Yuan Z, Liu J, Chen W, Lin C, Tao B, Liu B, Cai K:Peptide LL37 coating on micro-structured titanium implants to facilitate bone formation in vivo via mesenchymal stem cell recruitment. Acta Biomater 2018, 80:412-424.

39. Tuukkanen J, Koivukangas A, Jämsä T, Sundquist K, MacKay CA, Marks SC: Mineral Density and Bone Strength Are Dissociated in Long Bones of Rat Osteopetrotic Mutations. J Bone Miner Res 2000, 15:1905-1911.

40. Chauhan S, Sharma A, Upadhyay NK, Singh G, Lal UR, Goyal R: In-vitro osteoblast proliferation and in-vivo anti-osteoporotic activity of Bombax ceiba with quantification of Lupeol, gallic acid and $\beta$-sitosterol by HPTLC and HPLC. BMC Complement Altern Med 2018:18.

41. Domazetovic V, Marcucci G, Pierucci F, Bruno G, Di Cesare Mannelli L, Ghelardini C, Brandi ML, Iantomasi T, Meacci E, Vincenzini MT: Blueberry juice protects osteocytes and bone precursor cells against oxidative stress partly through SIRT1. FEBS Open Bio 2019, 9:1082-1096.

42. Zeiger E: Illusions of safety: antimutagens can be mutagens, and anticarcinogens can be carcinogens. Mutat Res / Reviews in Mutat Res 2003, 543:191-194.

43. Mody N, Parhami F, Sarafian TA, Demer LL: Oxidative stress modulates osteoblastic differentiation of vascular and bone cells. Free Radic Biol Med 2001, 31:509-519.

44. El-Tantawy WH, Al Haleem ENA: Therapeutic effects of stem cell on hyperglycemia, hyperlipidemia, and oxidative stress in alloxan-treated rats. Mol Cell Biochem. 2014, 391:193-200. 
45. Fowlkes JL, Bunn RC, Thrailkill KM. Contributions of the insulin/insulin-like growth factor-1 axis to diabetic osteopathy. J Diabetes Metab. 2011, 1(3):S1-003.

46. Tsentidis C, Gourgiotis D, Kossiva L, et al. Higher levels of s- RANKL and osteoprotegerin in children and adolescents with type 1 diabetes mellitus may indicate increased osteoclast signaling and predisposition to lower bone mass: a multivariate cross-sectional analysis. Osteoporos Int. 2016; 27:1631-1643.

47. Shah VN, Harrall KK, Shah CS, et al. Bone mineral density at femoral neck and lumbar spine in adults with type 1 diabetes: a meta-analysis and review of the literature. Osteoporos Int. 2017, 28:2601-2610.

48. Yano H, Ohya K, Amagasa T: Effects of Insulin on in vitro bone formation in fetal rat parietal bone. Endocr J. 1994, 41:293-300.

49. Cortizo AM, Sedlinsky C, McCarthy D, Blanco A, Schurman L: Osteogenic actions of the anti-diabetic drug metformin on osteoblasts in culture. Eur J Pharmacol. 2006, 536:38-46

50. Mai QG, Zhang ZM, Xu S, et al. Metformin stimulates osteoprotegerin and reduces RANKL expression in osteoblasts and ovariectomized rats. J Cell Biochem. 2011, 112:2902-2909.

51. Gao Y, Li Y, Xue J, Jia Y, Hu J: Effect of the anti-diabetic drug metformin on bone mass in ovariectomized rats. Eur J Pharmacol. 2010, 635:231-263.

52. Behera HN, Patnaik BK: Recovery from alloxan diabetes as revealed by collagen characteristics of bone, skin and tendon of Swiss Mice. Gerontology 1981, 27:32-36.

53. Villarino ME, Sánchez LM, Bozal CB, Ubios AM: Influence of short-term diabetes on osteocytic lacunae of alveolar bone. A histomorphometric study. Acta Odontol Latinoam 2006, 19:23-28.

54. Molinuevo MS, Schurman L, McCarthy AD, Cortizo AM, Tolosa MJ, Gangoiti MV, Arnol V, Sedlinsky C: Effect of metformin on bone marrow progenitor cell differentiation: in vivo and in vitro studies. J J Bone Miner Res 2010, 25: 211-221.

55. Spanheimer RG, Umpierrez GE, Stumpf V: Decreased collagen production in diabetic rats. Diabetes 1988, 37:371-376.

56. Pulido R, Bravo L, Saura-Calixto F: Antioxidant activity of dietary polyphenols as determined by a modified ferric reducing/antioxidant power assay. J Agric Food Chem 2000, 48:3396-3402.

57. Takebayashi J, Ishii R, Chen J, Matsumoto T, Ishimi Y, Tai A: Reassessment of antioxidant activity of arbutin: Multifaceted evaluation using five antioxidant assay systems. Free Radic. Res 2010, 44:473-478.

58. Jeszka-Skowron M, Krawczyk M, Zgoła-Grześkowiak A: Determination of antioxidant activity, rutin, quercetin, phenolic acids and trace elements in tea infusions: Influence of citric acid addition on extraction of metals. J Food Compos Anal 2015, 40:70-77.

59. Frei B, Higdon JV: Antioxidant Activity of Tea Polyphenols In Vivo: Evidence from Animal Studies. J Nutr 2003, 133(10):3275S-3284S.

60. Oka Y, Iwai S, Amano H, Irie Y, Yatomi K, Ryu K, Yamada S, Inagaki K, Oguchi K: Tea Polyphenols Inhibit Rat Osteoclast Formation and Differentiation. J Pharmacol Sci 2011, 118(1):55-64.

61. Hasan W, Ahmad S, Thakur H, Abbas M: In vitro regulation of osteoclast generation: a cost-effective strategy to combat osteoporosis with natural antioxidants and polyphenols like EGCG. Eur J Acad Res 2014, 2:2286-4822.

62. Nicolin, V., De Tommasi, N., Nori, S.L., Costantinides, F., Berton, F., Di Lenarda, R., 2019. Modulatory Effects of Plant Polyphenols on Bone Remodeling: A Prospective View From the Bench to Bedside. Front Endocrinol (Lausanne). 10, 494. 
63. Jayachandrana M, Wua Z, Ganesana K, Khalidb S, Chunga SM, Xua B: Isoquercetin upregulates antioxidant genes, suppresses inflammatory cytokines and regulates AMPK pathway in streptozotocin-induced diabetic rats. Chem-Biol Interact 2019, 303:62-69.

64. Kyung TW, Lee JE, Shin HH, Choi HS: Rutin inhibits osteoclast formation by decreasing reactive oxygen species and TNF- $\alpha$ by inhibiting activation of NF- $x$ B. Exp Mol Med 2008, 40:52-58.

65. Fayeda HA, Barakata BM, Elshaerb SS, Abdel-Naimc AB, Menzed ET: Antiosteoporotic activities of isoquercitrin in ovariectomized rats: Role of inhibiting hypoxia inducible factor-1 alpha. Eur J Pharmacol 2019, 865: 172785.

66. Horcajada-Molteni MN, Crespy V, Coxam V, Davicco MJ, Rémésy C, Barlet JP: Rutin Inhibits Ovariectomy-Induced Osteopenia in Rats. JBMR 2000, 15:2251-2258.

67. Yokoyama A, Sakakibara H, Crozier A, Kawai Y, Matsui A, Terao J, Kumazawa S, Shimoi K: Quercetin metabolites and protection against peroxynitrite-induced oxidative hepatic injury in rats. Free Radic Res 2009, 43:913-21.

68. Man X, Yang L, Liu S, Yang L, Li M, Fu Q: Arbutin promotes MC3T3-E1 mouse osteoblast precursor cell proliferation and differentiation via the Wnt/B-catenin signaling pathway. Mol Med Rep 2019, 19:4637-4644.

69. Prouillet C, Mazière J-C, Mazière C, Wattel A, Brazier M, Kamel S: Stimulatory effect of naturally occurring flavonols quercetin and kaempferol on alkaline phosphatase activity in MG-63 human osteoblasts through ERK and estrogen receptor pathway. Biochem Pharmacol 2004, 67:1307-1313.

70. Kanter M, Altan MF, Donmez S, Ocakci A, Kartal ME: The effects of quercetin on bone minerals, biomechanical behavior, and structure in streptozotocin-induced diabetic rats. Cell Biochem Funct 2007, 25:747-752.

71. Derakhshanian H, Ghadbeigi S, Rezaian M, Bahremand A, Javanbakht MH, Golpaie A, Hosseinzadeh P, Tajik N, Dehpour AR: Quercetin improves bone strength in experimental biliary cirrhosis. Hepatol Res 2013, 43:394-400.

72. Omori A, Yoshimura Y, Deyama Y, Suzuki K: Rosmarinic acid and arbutin suppress osteoclast differentiation by inhibiting superoxide and NFATc1 downregulation in RAW 264.7 cells. Biomed Reports 2015, 3:483-490.

73. Barhoma RA, Hegab II, Atef MM, El-Shamy AM: Unraveling the Role of Melatonin/ Quercetin in Attenuating the Metabolic and Bone Turnover Alternations in Iron TreatedOvariectomized Female Rats. Med J Cairo Univ 2019, 87:2857-2870.

74. Chen Y, Dai F, He Y, Chen Q, Xia Q, Cheng G, Lu Y, Zhang Q: Beneficial effects of hyperoside on bone metabolism in ovariectomized mice. Biomed Pharmacother 2018, 107:1175-1182.

75. Qi X-C, Li B, Wu W-L, Liu, H-C, Jiang Y-P: Protective effect of hyperoside against hydrogen peroxide-induced dysfunction and oxidative stress in osteoblastic MC3T3-E1 cells. Artif Cells Nanomedicine Biotechnol 2020. 48, 377-383.

76. Liu L, Wang D, Qin Y, Xu M, Zhou L, Xu W, Liu X, Ye L, Yue S, Zheng Q, Li D: Astragalin Promotes Osteoblastic Differentiation in MC3T3-E1 Cells and Bone Formation in vivo. Front Endocrinol (Lausanne) 2019, 10:228.

77. Karadeniz F, Oh JH, Lee JI, Seo Y, Kong CS: 3,5-dicaffeoyl-epi-quinic acid from Atriplex gmelinii enhances the osteoblast differentiation of bone marrow-derived human mesenchymal stromal cells via WnT/BMP signaling and suppresses adipocyte differentiation via AMPK activation. Phytomedicine 2020, 71:153225. 


\title{
OSTEOPROTEKTIVNI EFEKTI „ANTIDIJABETSKE“ BILJNE MEŠAVINE NA TIP 1 DIJABETIČNOM MODELU PACOVA
}

\author{
Aleksandra PETROVIĆ, Višnja MADIĆ, Marina JUŠKOVIĆ, \\ Ljubiša ĐORĐEVIĆ, Perica VASILJEVIĆ
}

Gubitak koštane mase, koji dovodi do osteopenije i osteoporoze, česta je sekundarna komplikacija dijabetesa. Cilj ovog istraživanja je procena vrednosti tradicionalno korišćene "antidijabetske" biljne mešavine kao mogući lek za prevenciju ove komplikacije. Dijabetes je indukovan kod ženki pacova Wistar ubrizgavanjem aloksan-monohidrata intraperitonealno. Životinje sa nivoom šećera u krvi većim od $20 \mathrm{mmol} / \mathrm{L}$ uzastopno 14 dana, smatrane su dijabetičnim. Tokom narednih 14 dana životinje su tretirane dvema koncentracijama biljne mešavine (10 i $20 \mathrm{~g}$ suvog biljnog materijala/kg). Dijabetične kontrolne grupe tretirane su insulinom glarginom (13 IU $/ \mathrm{kg})$, metforminom (150 $\mathrm{mg} / \mathrm{kg}$ ) i vodom. Zdrava kontrolna grupa je tretirana vodom. Histopatološka analiza kostiju procenjena je na osnovu hematoksilin-eozin i Mason-trihromnog bojenja. Dijabetes indukovan aloksanom je pokrenuo histopatološke promene na kostima karakteristične za nastanak osteopenije i osteoporoze, a tretman dekoktom biljne mešavine je te histopatološke promene vratio na fiziološki nivo. Takođe, tretman ovim testiranim dozama ne pokazuje toksične efekte. Na osnovu zapažanja biljna mešavina bi se mogla koristiti u prevenciji gubitka koštane mase kod dijabetičara. 